\title{
PENCAPAIAN KEPUASAN PELANGGAN PADA JASA PENGIRIMAN BARANG MELALUI HARGA, EKUITAS MEREK, DAN KUALITAS PELAYANAN
}

\author{
Rahayu Mardikaningsih \\ Universitas Mayjen Sungkono \\ rahayumardikaningsih@gmail.com
}

\begin{abstract}
ABSTRAK
Perkembangan industri jasa pengiriman barang berbanding lurus dengan dengan menyebarnya pandemi Covid19. Dengan alasan keamanan dan menekan penyebaran virus tersebut, masyarakat cenderung beralih dari pola belanja secara konvensional menjadi daring. Hal tersebut menjadi kesempatan bagi penyedia jasa pengiriman untuk meraih pelanggan-pelanggan setia melalui pencapaian kepuasan bagi mereka. Tulisan ini membahas tentang studi kepuasan pelanggan jasa pengiriman barang berdasarkan variabel harga, ekuitas merek dan kualitas pelayanan. Penelitian ditujukan kepada pelanggan yang menggunakan jasa pengiriman barang dari beragam merek di Kota Surabaya. Responden telah menggunakan jasa secara berkesinambungan dari salah satu merek pengiriman barang. Metode pengambilan sampel adalah non-probability sampling dengan teknik purposive sampling. Pengumpulan data dengan cara penyebaran kuesioner secara online memudahkan responden untuk mengisi pernyataan dan lebih efektif dan efesien perihal penggunaan biaya dan waktu dalam pengumpulan data. Ada 80 responden yang berhasil dikumpulkan. Analisis data pada penelitian ini menggunakan software SPSS 25 dan teknik analisis data yang digunakan analisis regresi linier berganda. Hasil penelitian membuktikan bahwa harga, ekuitas merek dan kualitas pelayanan berpengaruh signifikan terhadap kepuasan pelanggan jasa pengiriman. Variabel harga menjadi variabel yang berpengaruh dominan dibandingkan ekuitas merek dan kualitas pelayanan karena memiliki nilai koefesien regresi yang lebih besar.
\end{abstract}

Kata-kata kunci: Harga, Ekuitas Merek, Kualitas Pelayanan, Kepuasan Pelanggan

\section{PENDAHULUAN}

Di era pandemi Covid-19, seluruh bisnis di dunia mengalami dampak dan berusaha bertahan di tengah tekanan penurunan omset penjualan. Selain itu persaingan di industri juga menjadi sesuatu yang harus dihadapi untuk mempertahankan pelanggan-pelanggan setia dan memperoleh pelanggan baru (Arifin, 2020). Meski adanya pandemi namun jasa pengiriman barang justru meningkat di seluruh bagian industrinya. Sektor logistik menjadi salah satu industri yang berkembang secara signifikan. Hal tersebut karena perubahan perilaku masyarakat untuk berbelanja secara online dan menggunakan jasa pengiriman barang sebagai bentuk pencegahan meluasnya pandemi sehingga berbagai penyedia jasa logistik di Indonesia turut mencatat kenaikan volume pengiriman barang. Jasa pengiriman barang merupakan bagian utama dari transaksi secara online karena bersifat cepat, mudah, aman dan praktis dalam hal pengiriman barang. Kebutuhan konsumen yang semakin tinggi, serta berkembangnya bisnis toko online atau e-commerce menunjukkan tingginya antusiasme konsumen akan jasa pengiriman barang (Darmawan, 2021).

Respon pasar yang tinggi menyebabkan tuntutan konsumen semakin kompleks. Hal tersebut menyebabkan para pemasar harus mengamati pasar dan merespon dengan desain nilai tawaran yang mampu mewujudkan harapan konsumen (Kotler dan Keller, 2013). Pemenuhan kebutuhan konsumen saat ini lebih individualis dan menuntut segala hal minim kesalahan (Aaker, 2013). Untuk memenuhi harapan tersebut, pemasar harus mampu memahami keinginan dan kebutuhan konsumen secara tepat. Dengan demikian, strategi pemasaran harus tetap memperkuat keunggulan kompetitif agar nilai yang ditawarkan tetap unggul di antara pesaingnya dan porsi pangsa pasar tetap berkembang (Darmawan, 2017). Hal yang penting untuk memerhatikan kepuasan pelanggan sebagai dasar menuju keberhasilan bisnis berorientasi jangka panjang bagi perusahaan (Monavvarian et al., 2015).

Kepuasan pelanggan menjadi hal yang sering diamati di dunia pemasaran (Daryanto, 2014). Upaya meningkatkan kepuasan pelanggan menjadi salah satu formulasi strategi membentuk kesetiaan pelanggan melalui tingkatan perilaku yang lebih awal yaitu kesan yang baik dari mereka terhadap merek dan perusahaan, memberikan dampak kepada niat beli dan membentuk kebiasaan membeli ulang (Janghyeon et al., 2011; Awan dan Asad, 2014; Shahroudi dan Naimi, 2015). Kepuasan pelanggan dapat dipengaruhi oleh beberapa variabel seperti harga, ekuitas merek dan kualitas pelayanan (Darmawan, 2009; Aaker, 2013; Keller, 2013).

Dominique dan Proença (2016) menyatakan bahwa tanggapan terhadap harga memengaruhi kepuasan pelanggan dengan cara yang positif tetapi kewajaran harga yang dirasakan dapat dipengaruhi secara negatif oleh 
kerentanan pelanggan. Pelanggan menginginkan produk yang berkualitas baik dengan harga terjangkau yang dapat mereka beli dengan mudah dan jika ada perusahaan yang memberikan ini kepada pelanggan maka akan membangun hubungan jangka panjang yang baik dengan pelanggan (Leong dan Wang, 2006).

Ekuitas merek yang memilliki kekuatan akan berdampak pada daya tarik bagi konsumen dan menggiring pada keputusan pembelian (Keller, 2013). Merek yang kuat memiliki potensi untuk menarik pelanggan-pelanggan baru. Apabila konsumen memiliki kesan bahwa suatu merek memiliki diferensiasi yang menonjol dibanding pesaingnya maka kesan kualitas menjadi lebih mudah terbentuk dan melekat lebih lama untuk terus diperbandingkan dengan merek-merek lain. Hal ini mempermudah untuk melakukan komunikasi pemasaran. Karadeniz (2010) dan Monavvarian et al. (2015) menyatakan ekuitas merek dapat memberikan dampak positif terhadap kepuasan pelanggan. Aysel et al. (2012) menyatakan ekuitas merek dan kepuasan pelanggan dapat dimanfaatkan untuk menyampaikan kesan positif terhadap merek serta menutupi kesan negatif.

Menurut Lovelock dan Wright (2002), setelah melakukan pembelian, pelanggan membandingkan layanan yang diharapkan dengan apa yang sebenarnya diterima. Pelanggan memutuskan seberapa puas mereka dengan penyampaian dan hasil layanan, dan mereka juga membuat penilaian tentang kualitas. Setelah melalui proses pelayanan, pelanggan dapat mengevaluasi tingkat kepuasan atau ketidakpuasan dan dapat menggunakan informasi ini untuk memperbarui persepsi kualitas layanan (Parasuraman et al., 1985). Pelanggan harus mengalami layanan sebelum mereka dapat puas atau tidak puas dengan hasilnya. Meskipun para peneliti telah mempelajari konsep layanan selama beberapa dekade, tidak ada konsensus tentang konseptualisasi kualitas layanan (Cronin dan Taylor, 1992) karena peneliti yang berbeda berfokus pada aspek kualitas layanan yang berbeda. Ahangar (2011) meneliti dampak dari lima aspek kualitas layanan (daya tanggap, keandalan, efisiensi, privasi informasi dan kemudahan penggunaan) pada kepuasan pelanggan. Adanya premis bahwa hanya pelanggan yang menilai kualitas menyebabkan kualitas layanan didefinisikan sebagai penilaian tentang keunggulan layanan secara keseluruhan (Schneider dan White, 2004). Alasan penting untuk mengamati variabel kualitas pelayanan yang dilakukan akademisi dan praktisi adalah hasil tersebut akan memberikan menguntungkan pada umpan balik dari kinerja penyedia jasa.

Berdasarkan uraian sebelumnya maka studi ini mengambil topik tentang studi kepuasan pelanggan jasa pengiriman barang berdasarkan variabel harga, ekuitas merek dan kualitas pelayanan. Penelitian ditujukan kepada pelanggan yang menggunakan jasa pengiriman barang dari beragam merek di Kota Surabaya.

\section{LANDASAN TEORI DAN PENGEMBANGAN HIPOTESIS}

\section{Harga}

Harga merupakan salah satu bagian terpenting dalam memasarkan suatu produk karena harga merupakan salah satu dari empat bauran pemasaran (Djati, 2004). Harga adalah nilai tukar produk produk yang dinyatakan dalam satuan moneter (Khasanah, 2010). Harga merupakan ketetapan nilai suatu produk yang dinominalkan dalam bentuk uang (Sinambela, 2017)). Hal tersebut berbentuk sejumlah uang dalam pertukaran manfaat dan pengorbanan antar pihak. Harga menjadi dasar penting dari transaksi komersial yang dipertimbangkan dalam proses pertukaran kepemilikan. Menurut Kotler dan Keller (2013), kebijakan penetapan harga menentukan keberhasilan tawaran produk ke pasar sebab variabel ini selain memberikan pendapatan bagi perusahaan juga menjadi tolok ukur tingkat pengorbanan konsumen untuk memperoleh produk. Harga merupakan salah satu penentu keberhasilan suatu perusahaan karena harga menentukan seberapa besar keuntungan yang akan diperoleh perusahaan dari menjual produknya (Renneboog dan Spaenjers, 2013). Penetapan harga yang terlalu tinggi akan menyebabkan penjualan menurun, namun jika harga terlalu rendah akan mengurangi keuntungan yang dapat diperoleh organisasi perusahaan (Mardikaningsih dan Sinambela, 2016). Han et al. (2015) menyatakan bahwa pelanggan yang merasakan kesesuaian harga akan mendorong kepada kepuasan pelanggan. Hal tersebut akan tercapai saat pelanggan merasakan manfaat yang diinginkan dan menjadi percaya untuk melakukan pertukaran ulang.

\section{Ekuitas Merek}

Variabel ekuitas merek berperan penting keberlangsungan hidup suatu perusahaan dan menjadi salah satu luaran dari upaya pemasaran (Keller, 2013). Janghyeon et al. (2011) menyatakan merek dianggap sebagai nilai tangible dan intangible yang terwakili dalam sebuah merek dagang yang mampu membentuk nilai dan memberikan posisi di pasar. Lebih lanjut Janghyeon dan kawan-kawan menyatakan dengan adanya merek maka perlakuan 
intensif harus diarahkan untuk menguatkan merek. Ekuitas merek berkaitan dengan kekuatan merek. Ekuitas merek terkandung beragam aset dan kewajiban yang berhubungan dengan merek, nama, serta simbol yang menambah atau nilai yang diberikan produk kepada pelanggan (Aaker, 2013). Kotler dan Keller (2013) mendefinisikan ekuitas merek sebagai nilai utama yang melekat pada produk. Nilai ini mendeskripsikan cara konsumen bersikap terhadap merek. Menurut Morgan (2000), kepemilikan merek yang kuat mengharuskan perusahaan dapat mengatur aset mereka dengan baik. Selain itu merek yang kuat juga akan mengembangkan pangsa pasar dan meningkatkan pendapatan, menawarkan harga premium, menekan biaya komunikasi pemasaran, serta memperkuat keunggulan kompetitif. Saat ini merek sudah menjadi konsep yang kompleks dengan sejumlah ratifikasi teknis dan psikologis (Yanti dan Yuliana, 2018).

\section{Kualitas Pelayanan}

Kualitas pelayanan telah menjadi penilaian utama dari keunggulan pelayanan sebagai bagian inti produk yang disediakan oleh penyedia jasa. Kualitas pelayanan umumnya dicatat sebagai prasyarat penting dan penentu daya saing untuk membangun dan mempertahankan hubungan yang memuaskan dengan pelanggan (Masitoh, 2017). Perhatian terhadap kualitas pelayanan dapat membuat suatu organisasi berbeda dari organisasi lain dan memperoleh keunggulan kompetitif yang bertahan lama (Iskandar, 2003; Mardikaningsih, 2017). Kualitas pelayanan ditentukan oleh gap antara layanan yang diharapkan dan layanan yang dirasakan konsumen dari penyedia jasa sehingga hal tersebut menjadi petunjuk tentang keberhasilan atau kegagalan memenuhi harapan pelanggan (Cronin dan Taylor, 1992; Zeithaml et al., 1990).

Secara khusus, konsumen lebih menyukai kualitas pelayanan ketika harga dan elemen biaya lainnya tetap konstan (Sciffman dan Kanuk, 1991). Ini telah menjadi aspek yang berbeda dan penting dari penawaran produk dan layanan (Hendratno, 2003; Djati, 2005). Kepuasan yang diperoleh pelanggan dari kualitas pelayanan yang ditawarkan biasanya dievaluasi dalam hal kualitas teknis dan kualitas fungsional (Gronroos, 1984). Biasanya, pelanggan tidak memiliki banyak informasi tentang aspek teknis suatu layanan. Oleh karena itu, kualitas fungsional menjadi faktor utama yang membentuk persepsi kualitas pelayanan. Kualitas layanan dapat diukur dari persepsi pelanggan, harapan pelanggan, kepuasan pelanggan, dan sikap pelanggan (Ferrinadewi, 2004). Evaluasi kualitas pelayanan mengarah pada kepuasan pelanggan (Engel et al., 1995).

\section{Kepuasan Pelanggan}

Rust dan Oliver (1994) mendefinisikan kepuasan sebagai respon pemenuhan pelanggan, yang merupakan evaluasi sekaligus respons berbasis emosi terhadap suatu layanan. Kepuasan pelanggan merupakan perasaan senang atau kecewa seseorang yang timbul karena adanya perbandingan antara keinginan dan kinerja perusahaan yang berorientasi pada produk atau nilai yang ditawarkan terhadap harapan pelanggan (Darmawan, 2021). Zeithaml et al. (2002) menyatakan kepuasan pelanggan adalah penilaian pelanggan terhadap produk perihal menilai kemampuan produk untuk memenuhi kebutuhan dan harapan pelanggan. Shahroudi et al. (2015) berpendapat kepuasan pelanggan adalah sikap, penilaian respon emosional dari konsumen pasca pembelian. Menurut Kotler dan Keller (2013), pelanggan yang merasakan kepuasan akan memberikan respon lanjutan berupa kesetiaan dalam bentuk peningkatan jumlah pembelian dan membicarakan kebaikan tentang produk. Mereka menjadi tidak peka terhadap tawaran pesaing (Sinambela dan Widyawati, 2021). Variabel ini diukur dengan beberapa metode seperti survei kepuasan pelanggan, riset pasar maupun forum diskusi yang dilakukan secara daring (Darmawan, 2009; Karina, 2012). Upaya untuk memuaskan pelanggan diperlukan untuk bertahan di tengah persaingan, memperbesar pangsa pasar dan menambah pelanggan-pelanggan setia (Dlacic dan Kezman. 2014). Sementara itu, Dutka (2008) menilai kepuasan pelanggan melalui tiga atribut kepuasan pelanggan, yaitu attributes related to product, attributes related to service, dan attributes related to purchase. Atribut pertama adalah atribut berkaitan dengan produk yang mengarah kepada hal-hal yang berwujud atau yang tidak berwujud seperti warna, kemasan, pabrik atau pengecer, dan pelayanan sehingga dapat memuaskan keinginan dan kebutuhan. Atribut kedua adalah terkait dengan pelayanan saat proses dan pasca pembelian. Pandangan ini terbentuk dari evaluasi konsumen pasca pembelian dari proses pengambilan keputusan, konsumsi hingga pemenuhan kebutuhan. Atribut terakhir berkaitan dengan keputusan yang diambil konsumen yang dipengaruhi oleh berbagai stimulus seperti komunikasi pemasaran dan pengaruh lainnya dari perusahaan.

\section{Hipotesis}

H1: Ada pengaruh harga terhadap kepuasan pelanggan jasa pengiriman barang.

$\mathrm{H} 2$ : Ada pengaruh ekuitas merek terhadap kepuasan pelanggan jasa pengiriman barang.

H3: Ada pengaruh kualitas pelayanan terhadap kepuasan pelanggan jasa pengiriman barang. 


\section{METODOLOGI PENELITIAN}

Populasi di studi ini adalah pengguna jasa pengiriman. Sampel di studi ini adalah pengguna jasa pengiriman barang di Kota Surabaya dengan kriteria usia minimal 17 tahun. Responden telah menggunakan jasa secara berkesinambungan dari salah satu merek pengiriman barang. Metode pengambilan sampel adalah nonprobability sampling dengan teknik purposive sampling. Pengumpulan data dengan cara penyebaran kuesioner secara online memudahkan responden untuk mengisi pernyataan dan lebih efektif dan efesien perihal penggunaan biaya dan waktu dalam pengumpulan data. Ada 80 yang berhasil dikumpulkan dan diolah lebih lanjut. Pengukuran semua konstruk di model penelitian diukur menggunakan skala likert Agree-Disagree dengan empat pilihan, setuju, agak setuju, kurang setuju, dan tidak setuju. Analisis data di penelitian ini dibantu software SPSS 25 dan teknik analisis data yang digunakan analisis regresi linier berganda.

\section{HASIL PENELITIAN}

Data dari responden yang berhasil dikumpulkan adalah sebanyak 80 orang. Data tersebut akan diuji validitasnya. Uji validitas setiap pernyataan yang ditujukan kepada responden diharuskan mempunyai nilai person correlation lebih besar dari 0,30 (Hair et al., 1998). Hal tersebut akan menunjukkan data dari variabel yang diteliti secara tepat layak untuk dipergunakan di penelitian. Hasil output SPSS seperti ditunjukkan Tabel 1 hanya ada satu item pernyataan yang digugurkan karena memiliki nilai 0,298.

Tabel 1. Uji Validitas

\begin{tabular}{|c|c|c|c|c|}
\hline No & Variabel & Indikator & Korelasi & Keterangan \\
\hline \multirow[t]{4}{*}{1} & Harga & X.1.1 & 0,503 & valid \\
\hline & & X.1.2 & 0,611 & valid \\
\hline & & X.1.3 & 0,593 & valid \\
\hline & & X.1.4 & 0,565 & valid \\
\hline \multirow[t]{5}{*}{2} & Ekuitas Merek & X.2.1 & 0,754 & valid \\
\hline & & X.2.2 & 0,702 & valid \\
\hline & & X.2.3 & 0,643 & valid \\
\hline & & X.2.4 & 0,298 & Tidak valid \\
\hline & & X.2.5 & 0,419 & valid \\
\hline \multirow[t]{5}{*}{3} & Kualitas Pelayanan & X.3.1 & 0,632 & valid \\
\hline & & X.3.2 & 0,673 & valid \\
\hline & & X.3.3 & 0,522 & valid \\
\hline & & X.3.4 & 0,784 & valid \\
\hline & & X.3.5 & 0,633 & valid \\
\hline \multirow[t]{5}{*}{4} & Kepuasan Pelanggan & Y.1 & 0,749 & valid \\
\hline & & Y.2 & 0,851 & valid \\
\hline & & Y.3 & 0,427 & valid \\
\hline & & Y.4 & 0,319 & valid \\
\hline & & Y.5 & 0,303 & valid \\
\hline
\end{tabular}

Hasil uji reliabilitas yang menggunakan pedoman nilai Cronbach's Alpha $>0,6$ menunjukkan bahwa semua variabel memenuhi hal tersebut seperti terlihat pada Tabel 2. Hasil tersebut memberikan makna bahwa alat ukur konsisten bila digunakan kembali untuk mengamati obyek yang serupa.

Tabel 2. Uji Reliabilitas

\begin{tabular}{clcc}
\hline No & \multicolumn{1}{c}{ Variabel } & Cronbach's Alpha & Keterangan \\
\hline $\mathbf{1}$ & Harga & 0,686 & Reliabel \\
\hline $\mathbf{2}$ & Ekuitas Merek & 0,772 & Reliabel \\
\hline $\mathbf{3}$ & Kualitas Pelayanan & 0,731 & Reliabel \\
\hline $\mathbf{4}$ & Kepuasan Pelanggan & 0,884 & Reliabel \\
\hline
\end{tabular}

Sumber dari output SPSS 
Selanjutnya dilakukan uji normalitas seperti pada Tabel 3 yang menggunakan metode Kolmogorov-Smirnov. Ketentuan yang digunakan adalah signifikansi di atas 0,05 . Hasil yang diperoleh adalah 0,336 sehingga dapat dinyatakan data yang terkumpul memiliki distribusi secara normal.

Tabel 3. Uji Kolmogorov-Smirnov Z

\begin{tabular}{llr}
\hline & & Unstandardized Residual \\
\hline $\mathbf{N}$ & & 80 \\
\hline Normal Parameters(a,b) & Mean & .0000000 \\
\hline & Std. Deviation & .52440453 \\
\hline & Absolute & .064 \\
\hline & Positive & .042 \\
\hline & Negative & -.064 \\
\hline Kolmogorov-Smirnov $\mathbf{Z}$ & & .889 \\
\hline Asymp. Sig. (2-tailed) & & .336 \\
\hline
\end{tabular}

Sumber dari output SPSS

Dasar penentuan uji t di penelitian ini dengan membandingkan nilai signifikan dengan batas atas sebesar 0,05. Nilai yang berada di bawah 0,05 menunjukkan variabel bebas dinyatakan berpengaruh secara signifikan terhadap variabel terikat. Pada Tabel 4, nilai signifikan masing-masing variabel bebas berada di bawah 0,05.

Tabel 4. Uji t

\begin{tabular}{|c|c|c|c|c|c|c|}
\hline \multirow{2}{*}{\multicolumn{2}{|c|}{ Model }} & \multicolumn{2}{|c|}{ Unstandardized Coefficients } & \multirow{2}{*}{$\frac{\text { Standardized Coefficients }}{\text { Beta }}$} & \multirow[t]{2}{*}{$\mathrm{t}$} & \multirow[t]{2}{*}{ Sig. } \\
\hline & & $\mathrm{B}$ & Std. Error & & & \\
\hline \multirow[t]{4}{*}{1} & (Constant) & 5.481 & 1.628 & & 3.366 & .001 \\
\hline & X.1 & 4.363 & .273 & .538 & 15.976 & .000 \\
\hline & $\mathrm{X} .2$ & 2.310 & .184 & .402 & 12.529 & .000 \\
\hline & $\mathbf{X . 3}$ & 1.368 & .207 & .195 & 6.606 & .000 \\
\hline
\end{tabular}

Masing-masing variabel bebas memiliki nilai signifikan 0,000 yang berarti lebih kecil daripada 0,05 . Berdasarkan hal tersebut maka ditetapkan bahwa harga berpengaruh secara signifikan terhadap kepuasan pelanggan. Ekuitas merek berpengaruh secara signifikan terhadap kepuasan pelanggan. Kualitas pelayanan berpengaruh secara signifikan terhadap kepuasan pelanggan. Persamaan regresi yang dihasilkan adalah $\mathrm{Y}=$ $5,581+4,363 X .1+2,310 X .2+1,368 X .3$. Variabel harga menjadi variabel yang berpengaruh dominan dibandingkan ekuitas merek dan kualitas pelayanan karena memiliki nilai koefesien regresi yang lebih besar.

Tabel 5. Uji F

\begin{tabular}{llrrrrr}
\hline Model & Sum of Squares & df & Mean Square & F & Sig. \\
\hline 1 & Regression & 6645.645 & 3 & 2215.215 & 544.416 & $.000^{\mathrm{b}}$ \\
\cline { 2 - 7 } & Residual & 309.242 & 76 & 4.069 & & \\
\cline { 2 - 6 } & Total & $\mathbf{6 9 5 4 . 8 8 8}$ & $\mathbf{7 9}$ & & & \\
\hline \multicolumn{7}{c}{ Sumber dari output SPSS }
\end{tabular}

Tabel 5 adalah hasil uji F di penelitian ini. Nilai signifikan untuk uji F pada penelitian ini $0,000<0,05$. Hasil ini menyimpulkan bahwa ada pengaruh yang signifikan secara simultan dari variabel harga, ekuitas merek, dan kualitas pelayanan terhadap kepuasan pelanggan.

Tabel 6. Model Summary

\begin{tabular}{lcrrr}
\hline Model & R & R Square & Adjusted R Square & Std. Error of the Estimate \\
\hline $\mathbf{1}$ & $\mathbf{. 9 7 8}^{\text {a }}$ & $\mathbf{. 9 5 6}$ & $\mathbf{9 5 4}$ & $\mathbf{2 . 0 1 7 1 7}$ \\
\hline \multicolumn{4}{c}{ Sumber dari output SPSS }
\end{tabular}




\section{PEMBAHASAN}

Besaran koefisien determinasi menunjukkan kemampuan variabel bebas harga, ekuitas merek dan kualitas pelayanan untuk menjelaskan variabel terikat kepuasan pelanggan. Nilai yang diperoleh adalah sebesar 0,954 atau sebesar $95,4 \%$. Angka tersebut memberi makna bahwa perubahan variabel terikat dipengaruhi oleh variabel bebas sebesar 95,4\%, sedangkan 4,6\% dipengaruhi oleh faktor lain di luar penelitian ini. Nilai R sebesar 0,978. Nilai 0,978 tersebut berada pada rentang 0,799-0,999, itu artinya antara variabel bebas dan variabel terikat memiliki hubungan yang sangat kuat.

Dengan demikian dari analisis data diperoleh temuan bahwa ketiga variabel bebas memiliki pengaruh yang signifikan terhadap variabel terikat. Harga memiliki pengaruh yang signifikan terhadap kepuasan pelanggan pengiriman barang. Temuan ini mendukung studi dari Grewal et al. (1998); Purnamasari et al. (2002); Leong dan Wang (2006); Dapkevičius dan Melnikas (2009); Kaura (2012); Malik dan Ghaffor (2012); Hanaysha (2016); Dominique dan Proença (2016); dan Darmawan (2019). Harga merupakan salah satu faktor yang paling rentan dari suatu produk. Ketika harga suatu produk tinggi maka konsekuensinya adalah kualitas suatu produk juga baik. Namun jika penyedia jasa menaikkan harga tanpa meningkatkan kualitas maka kepuasan pelanggan akan berkurang sehingga dapat dikatakan bahwa harga berpengaruh terhadap kepuasan pelanggan.

Ekuitas merek memiliki pengaruh yang signifikan terhadap kepuasan pelanggan pengiriman barang. Temuan ini mendukung studi dari Ravi dan Pascale (2006); Karadeniz (2010); Aysel et al. (2012); Ali dan Muqadas. (2015); Ahmad dan Sherwani (2015); dan Monavvarian et al. (2015). Ekuitas merek yang kuat adalah identik dengan nama merek yang dikenal, kesan kualitas, asosiasi merek yang kuat dan aset-aset lainnya seperti paten dan merek dagang. Ekuitas merek yang kuat ditandai dengan kondisi pelanggan yang memilih merek meski ada tawaran lain dari merek-merek lain dengan faktor-faktor unggul. Ekuitas merek yang lemah ditandai saat pelanggan tidak tertarik pada merek dan membeli karena faktor lain seperti karakteristik produk, harga, dan kenyamanan. Ekuitas merek yang kuat dapat membentuk kepuasan pelanggan.

Kualitas pelayanan memiliki pengaruh yang signifikan terhadap kepuasan pelanggan pengiriman barang. Temuan ini mendukung studi dari Oliver (1993); Purnamasari et al. (2002); Darmawan (2004); Dapkevičius dan Melnikas (2009); Ahangar (2011); Malik dan Ghaffor (2012); Nasir et al. (2014); Azim et al. (2014) dan Al-Tit (2015). Kualitas pelayanan merupakan indikator penting untuk mengukur kepuasan pelanggan. Peningkatan dan penurunan kepuasan pelanggan dipengaruhi oleh kualitas pelayanan. Dengan beberapa pelayanan yang baik seperti memberikan waktu untuk membantu pelanggan, keterampilan komunikasi yang baik, dapat memberikan informasi tentang produk kepada pelanggan sehingga kepuasan pelanggan akan meningkat. Jika perusahaan meningkatkan kualitas pelayanan maka pelanggan akan lebih terpuaskan, dan jika perusahaan menurunkan kualitas pelayanan tentunya pelanggan tidak akan puas (Darmawan, 2010). Oleh karena itu kualitas pelayanan sangat berpengaruh terhadap kepuasan pelanggan.

\section{PENUTUP}

Hasil penelitian ini membuktikan hipotesis penelitian telah benar bahwa harga, ekuitas merek dan kualitas pelayanan berpengaruh signifikan terhadap kepuasan pelanggan jasa pengiriman. Berdasarkan hasil penelitian ini, penulis berharap dapat memberikan kontribusi bagi pihak manajemen jasa pengiriman dengan memberikan informasi tentang harga dan kualitas pelayanan yang menjadi harapan pelanggan yang didukung pula dengan ekuitas merek sehingga dapat mewujudkan kepuasan bagi para pelanggan. Bagi perusahaan seharusnya tiada berhenti untuk membangun kekuatan merek yang lebih handal di tengah persiangan untuk memberikan dampak kepada kepuasan pelanggan. Perusahaan juga perlu memerhatikan kesan positif konsumen terhadap merek untuk meraih kesetiaan pelanggan melalui kepuasan. Masing-masing jasa pengiriman bersaing dengan tingkat harga yang dapat diterima oleh konsumen dan menjaga harapan mereka terpenuhi dengan cara mewujudkan pencapaian kepuasan. Kualitas pelayanan harus terus ditingkatkan agar para konsumen memiliki pengalaman yang baik dengan merek sehingga akan meningkatkan ekuitas merek itu sendiri seperti pengiriman barang tepat waktu atau barang yang dikirim tetap dalam kondisi terjaga. Adanya pengalaman yang baik akan memberikan peluang lebih besar untuk para konsumen kembali menggunakan jasa pengiriman tersebut. 


\section{DAFTAR PUSTAKA}

Aaker, David. A. (2013). Manajemen Pemasaran Strategi. Edisi Kedelapan. Jakarta: Salemba Empat.

Ahangar, Reza Gharoie. (2011). An Investigation into the Determinant of Customers' Preferences and Satisfaction of Internet Banking: Empirical Study of Iranian Banking Industry. Journal of Applied Sciences, 11 (3), 426-437.

Ahmad, Farah \& Najeeb Sherwani. (2015). An Emprical Study on the effect of Brand Equity of Mobile Phones on Customer Satisfaction. International Journal of Marketing Studies, 7, 40-49.

Ali, Fouzia \& Salma Muqadas. (2015). The Impact of Brand Equity on Brand Loyalty: The Mediating Role of Customer Satisfaction. Pakistan Journal of Commerce and Social Sciences, 9 (3), 890-915.

Al-Tit, A. A. (2015). The effect of service and food quality on customer satisfaction and hence customer retention. Asian Social Science, 11 (23), 129-139.

Arifin, S. \& D. Darmawan. (2020). Studi tentang Persepsi Nilai, Kepuasan dan Retensi Pelanggan Kapal Penyeberangan Ujung -Kamal. Jurnal Baruna Horizon, 3(1), 198-209.

Awan, Abdul Ghafoor. \& Asad Rehman. (2014). Impact of customer satisfaction on brand loyalty an empirical analysis of home appliances in Pakistan. British Journal of Marketing Studies, 2 (8), 18-32.

Azim, A., N. A. Shah, Z. Mehmood, S. Mehmood, \& M. Bagram. (2014). Factors effecting the customer's selection of restaurants in Pakistan. International Review of Management and Business Research, 3 (2), 10031013.

Cronin, J. J. Jr. \& S. A. Taylor. (1992). Measuring service quality: A re-examination and extension. Journal of Marketing, 56, 55-68.

Dapkevicius, Aurimas \& B. Melnikas. (2009). Influence of Price and Quality to Customer Satisfaction: Neuromarketing Approach. Business in XXI Century, 1 (3), 17-20.

Darmawan, D. (2004). Pengaruh Persepsi Kualitas Layanan, Citra Merek, dan Kepuasan Nasabah terhadap Respon Perilaku Nasabah. Jurnal Ilmiah Manajemen dan Akuntansi, 1(1), 33-47.

Darmawan, D. (2004). Pengaruh Kualitas Layanan terhadap Kepuasan Penumpang Kapal Feri Penyeberangan Ujung-Kamal, Jurnal Ekonomi dan Bisnis, 8(2), 39-44.

Darmawan, D. (2009). Ekuitas Pelanggan, Strategi Menciptakan Pelanggan Setia. Surabaya: Metromedia.

Darmawan, D. (2009). Pemasaran Jasa. Bandung: IntiPresindo Pustaka.

Darmawan, D. (2010). Manajemen Pemasaran. Bandung: IntiPresindo Pustaka.

Darmawan, D. (2017). Manajemen Ritel. Surabaya: Revka Prima Media.

Darmawan, D. (2019). Kualitas Produk, Kesadaran Merek dan Harga serta Pengaruhnya terhadap Kepuasan Pelanggan, Jurnal Administrasi Bisnis, 8(2), 75-88.

Darmawan, D. $\left(2021^{\mathrm{a}}\right)$. Understanding Impulsive Buying Behavior in Marketplace. Journal of Social Science Studies 1(1), 11-18.

Darmawan, D. (2021 ${ }^{\mathrm{b}}$ ). Pencapaian Kepuasan dan Loyalitas Pelanggan melalui Strategi Pemasaran Berdasarkan Pengalaman (Studi Kasus Pelanggan Rumah Makan Ayam Bakar Wong Solo di Mojokerto). Jurnal Manajemen, Bisnis, dan Kewirausahaan, 1(1), 1-13.

Daryanto \& Ismanto Setyabudi. (2014). Konsumen dan Pelayanan Prima. Yogyakarta: Gava Media.

Djati, S. Pantja \& D. Darmawan. (2004). Pengaruh Kesan Kualitas Layanan, Harga dan Kepuasan mahasiswa PTS terhadap Minat Mereferensi Kampusnya. Jurnal Widya Manajemen dan Akuntansi, 4(2), 190-204. 
Djati, S. Pantja \& D. Darmawan. (2005). Pengaruh Citra Merek dan Citra Pengecer terhadap Respon Merek dan Respon Pengecer melalui Kepuasan Merek dan Kepuasan Pengecer. Jurnal Ekonomi dan Keuangan, 9(1), 126143.

Dlacic, Jasmina. \& Elvedina Kezman. (2014). Exploring Relationship Between Brand Equity and Customer Loyalty on Pharmaceutical Market. International Journal Economic and Business Review. 16(2), 121-131.

Dominique, Sergio. \& Helder Vasconcelos João Ferreira F Proença. (2016). Determinants of customer price sensitivity: An empirical analysis. Global Journal of Management and Business Research: E-Marketing, 30 (3), 327-340.

Dutka, Alan. (2008). AMA Hand Book for Customer Satisfaction. Lincolnwood, Illinois. NTC Business Book.

Engel, J. F., Blackwell, R. D. \& Miniard, P. W. (1995). Consumer Behavior. (8th ed.) Orldano, FL: The Dryden Press.

Ercis, Aysel., Sevtap Unal, F. Burcu Candan \& Hatice Yildirim. (2012). The effect of brand satisfaction, trust and brand commitment on loyalty and repurchase intentions. Journal of International Strategic Management Conference, 5(8), 1-10.

Ferrinadewi, E \& D. Darmawan. (2004). Perilaku Konsumen: Analisis Model Keputusan. Yogyakarta: Universitas Atma Jaya.

Grewal, D., K. B. Monroe, \& R. Krishnan. (1998). The effects of price-comparison advertising on buyers'perceptions of acquisitions value, transaction value, and behavioural intentions. Journal of Marketing, 62 (2), 46-59.

Gronroos. (1984). A service quality model and its marketing implications. European Journal of Marketing, 18 (4), 36-44.

Hair, Joseph F. Jr., Rolph E Anderson., Ronald L Tatham., \& William C Black. (1998). Multivariate Data Analysis, 5th ed., Upper Saddle River: Prentice Hall International Inc.

Han, Heesup. \& Sunghyup Sean Hyun. (2015). Customer retention in the medical tourism industry: Impact of quality, satisfaction, trust, and price reasonableness. Tourism Management, 46, 20-29.

Hanaysha, J. (2016). Testing the effects of food quality, price fairness, and physical environment on customer satisfaction in fast food restaurant industry. Journal of Asian Business Strategy, 6 (2), 31-40.

Hendratno D. S. \& D. Darmawan. (2003). Dampak Kepuasan Nasabah terhadap Loyalitas Nasabah dan Perilaku Menabung, Jurnal Bisnis, Ekonomi dan Sosial, 3(2), 1-19.

Iskandar, Mochamad. \& D. Darmawan. (2003). Strategi Pemasaran. Bandung: IntiPresindo Pustaka.

Janghyeon, Nam Kyungnam, Yuksel Ekinci, \& Georgina Whyatt. (2011). Brand equity and brand loyalty and Consumer Satisfaction. Journal Annals of Tourism Research, 38 (3), 1009-1030.

Karadeniz, Mustafa. (2010). The Importance of Customer Based Strategic Brand Equity Management for Enterprises. Journal of Naval Science and Engineering. 6 (2), 117-132.

Karina, Ana., Toni Baskoro K. \& D. Darmawan. (2012). Pengantar Psikologi. Jakarta: Addar Press.

Kaura, V. (2012). A link for perceived price, price fairness and customer satisfaction. Pacific Business Review International Journal, 5 (6), 84-88.

Khasanah, Hikmahtul., Setya Arum., D. Darmawan. (2010). Pengantar Manajemen Bisnis. Jakarta: Spektrum Nusa Press.

Keller, Kevin Lane. (2013). Strategic Brand Management Building Measuring and Managing Brand Equity (4th ed.). USA: Pearson Education. 
Kotler, Philip \& Kevin Lane Keller. (2013). Marketing Management (14th ed.). Edinburgh Gate: Pearson Education.

Leong, Yow Peng. \& Qing Wang. (2006). Impact of Relationship Marketing Tactics (RMTs) on Switchers and Stayers in a Competitive Service Industry. Journal of Marketing Management, 22(1-2), 25-59.

Lovelock, C. \& R. Wright. (2002). Principles of Service Marketing and Management. 2nd ed. New Jersey: Pearson Education Inc.

Malik, E. \& M. Ghaffor. (2012). Impact of brand image, service quality and price on customer satisfaction in Pakistan telecommunication sector. International Journal of Business and Social Science, 3 (23), 123-129.

Mardikaningsih, R. (2017). Perencanaan Bisnis. Surabaya. Metromedia.

Mardikaningsih, R. (2017). Manajemen Bisnis Ritel. Surabaya. Metromedia.

Mardikaningsih, R. \& E. A. Sinambela. (2016). Peranan Komunikasi Pemasaran, Citra Merek Dan Kepercayaan Merek Terhadap Kesetiaan Merek. Jurnal Ilmu Manajemen, 2(1), 33-52.

Masitoh, D., D. Darmawan \& E. A. Sinambela. (2017). The Effect of Service Quality and Trust on Customer Loyalty of Warung Apung Rahmawati of Mojokerto Branch. Jurnal Agrimas, 1(2), 107-114.

Monavvarian, Abbas., Naser Asgari. \& Adel Roustaei Hoseinabadi. (2015). Studying The Effects of Brand Equity on The Consumers Responses in The Service Markets. International Journal of Economics, Commerce and Management, 3 (3), 1-18.

Morgan, R. P. (2000). A Consumer Orientated Framework of Brand Equity and Loyalty. International Journal of Market Research, 42 (1), 65-78.

Nasir, A., M. A. Ahmed, I. Nazir, H. Zafar, \& Z. Zahid. (2014). Impact of different determinants on customer"es satisfaction level (A case of fastfood restaurant). International Journal of Business and Management Invention, $3(9), 32-40$.

Oliver, R. L. (1993). A conceptual model of service quality and service satisfaction: compatible goals and different concepts, In Swart, T. A., Bowen, D. E., and Brown, S. W. (eds.) advances in service marketing and management: Research and Practice, 2nd ed. Greenwich, CT, 65-85. JAI press.

Parasuraman, A., V. A. Zeithaml, V. A., \& L. L. Berry, L. L. (1985). A conceptual model of service quality and its implications for future research. Journal of Marketing, 49, 41-50.

Purnamasari, Eliasinta, D. Darmawan, \& D. Baskara. (2002). Bauran Pemasaran dan Kualitas Layanan serta Pengaruhnya terhadap Kepuasan dan Loyalitas Pelanggan. Jurnal Ilmu Manajemen, 3(1), 34-46.

Ravi, P. \& Q. Pascale. (2006). Does customer Satisfaction lead to Improved brand equity? An emprical examination of to categories of retail brand. Journal of Product \& Brand Management, 15, 4-14.

Renneboog, L. \& C. Spaenjers. (2013). Buying beauty: On prices and returns in the art market. Management Science, 59 (1), 36-53.

Rust, R.T. \& R. L. Oliver. (1994). Service Quality: New Directions in Theory and Practice. Thousand Oaks, 119. Sage Publications.

Schiffman, Leon G. \& Leslie L. Kanuk. (1991). Consumer Behaviour, Fourth Edision, UK: Prentice Hall International Limited.

Schneider, B. \& S.S. White. (2004). Service quality: Research perspectives. Thousand Oaks, CA: Sage Publication. 
Shahroudi., Kambiz \& Seyedeh Safoura Naimi. (2015). The Impact of Brand Image on Customer Satisfaction and Loyalty Intention (Case Study: Consumer of Hygiene Products). International Journal of Engineering Innovation \& Research, 3(1), 2277 - 5668.

Sinambela, E. A. (2017). Pengaruh Ekuitas Merek dan Harga terhadap Keputusan Pembelian Produk Kopi Bubuk Kemasan. Management \& Accounting Research Journal, 1(2), 44-49.

Sinambela, E. A. \& Nur Widyawati. (2021). Studi tentang Citra Toko, Gaya Hidup, dan Keputusan Pembelian di Toko Busana Muslim. Jurnal Manajemen, Bisnis, dan Kewirausahaan, 1(1), 39-51.

Yanti, Yulianti. \& Yuliana. (2018). Manajemen Pemasaran, IntiPresindo Pustaka, Bandung.

Zeithaml, V. A., A. Parasuraman, \& A. Malhotra. (2002). Service quality delivery through web sites: a critical review of extant knowledge. Journal of the academy of marketing science, 30 (4), 362-375.

Zeithaml, V. A., A. Parasuraman, A., \& L.L. Berry, L. L. (1990). Delivering quality service: Balancing customer perceptions and expectations. New York, NY: Free Press. 